\title{
Dear Reader,
}

The unique theme of this year's third issue of Opus et Educatio is the importance of soft skills in the labour market and education's response to this growing demand in the 21st century.

The first study of our recent issue, written by Ildikó Holik and Dániel István Sanda, presents their research in technical higher education, which aimed to map the competencies of engineering informatics students and determine development opportunities. Courses that focus on self-knowledge and self-esteem and the development of cooperation, adaptation, confidence-building, and empathic skills were rated as extremely important. Cooperative methods, collaborative learning, project method and problem-based learning also play a fundamental role in higher education. Helena Manojlovic's study presents a self-developed method for advancing soft skills. This method is the educational escape room, which offers a new learning opportunity that enhances learning with engaging experiences, and in parallel, evolves soft skills through solving complex problems. Applying critical thinking and problem-solving skills is essential, and lack of time encourages students to collaborate. Finally, Zsófia Kocsis writes about students' part-time work related to their studies to gain exceptional professional experience and relationships. However, even work not related to the studies may develop skills and abilities.

Agnes Fazekas, Tibor Baráth and Tamas Kersanszki presented theoretical models created during their student organization research. The interviewed teachers and leaders are typically satisfied with the quality and effectiveness of pedagogical work in their school; the most advanced learning organization dimensions are shared goals, vision, risk-taking and innovation willingness. Knowledge-focused leadership, responsibility, collaboration, knowledge sharing is missing. György Molnár highlights in his study that teaching effectiveness also depends on teachers knowing when to use digital technology and when to stick to traditional methods. In the recent pandemic, the technological challenges have been replaced by pedagogical and methodological challenges during online education. This required the long-term preservation of crucial competencies, highlighting understanding, patience, resilience, collaborative thinking, working together online, and maintaining a cooperative perspective. Ottília Fülöp presents student feedback, suggesting that university mathematics courses can be efficiently transformed into a digital format. A surprising result of their research was that students felt communication with the instructor was more direct and closer during online learning than in face-toface classes with the same instructor.

In the world of work section of our recent issue, two topics are displayed. First, Monika Pogatsnik reviews the purpose and benefits of dual training and shares first-hand information on practice and training sites. Bringing the world of trainers and the world of work closer together can increasingly meet the economic challenges of the 21st century. In addition to professional knowledge, the on-thejob practice provides an additional opportunity to develop soft skills that are highly valued by employers nowadays. These skills can best be developed during activities, e.g., communication skills, cooperation skills, networking. Judit Módné Takács points out that the development of soft skills positively affects security awareness and expected competencies in today's job market. Additionally, cybersecurity as a competency has grown into a 21st-century, essential, scalable skill. Therefore, new training methods, systems and measuring systems are required considering different skills, ages and generational characteristics, improving safety awareness attitude.

In the consciousness section of our recent issue, you can read about a unique country, Myanmar, and the role of teacher education in the curriculum reform of primary education since 2010 . Whether the new curriculum in basic education can be implemented remains in question in the current political situation. For the future generations of Myanmar students, humanitarian aid from the international community should continue to support curriculum improvements. 
In the Project section, we present the OPENSSL Project. In the framework of the innovative project, partners from Hungary, the Netherlands, and Malta collaborate to create three Massive Open Online Courses (MOOC) for higher education students developing social-emotional skills that are highly relevant for employability: presentation skills, teamwork, stress management skills.

In the review section, István Simon reports the release of the first volume of a new series, the Vocational Training Pedagogical Scientific Publications (Szakképzés-Pedagógiai Tudományos Közlemények) edited by András Benedek. The aim of the volume, including 16 studies, is to present research results arousing the interest of other researchers, initiate further scientific discussions and research activities.

As the guest editor of this issue, I hope that by focusing on a timely and interesting topic to our readers, in addition to professional exchange and practical use, we have also provided an incentive for further empirical.

Budapest, September 2021

\section{Monika Pogatsnik}

Guest Editor of this Issue 